\title{
BMJ Open The inter-relationship among economic activities, environmental degradation, material consumption and population health in low-income countries: a longitudinal ecological study
}

\author{
Ying-Chih Chuang, ${ }^{1}$ Ya-Li Huang, ${ }^{2}$ Ching-Yao Hu, ${ }^{1}$ Ssm-Ching Chen, ${ }^{1}$ \\ Kuo-Chien Tseng ${ }^{1}$
}

To cite: Chuang $Y-C$, Huang Y-L, Hu C-Y, et al. The inter-relationship among economic activities, environmental degradation, material consumption and population health in lowincome countries: a longitudinal ecological study. BMJ Open 2015;5: e006183. doi:10.1136/ bmjopen-2014-006183

- Prepublication history and additional material is available. To view please visit the journal (http://dx.doi.org/ 10.1136/bmjopen-2014006183).

Received 28 July 2014 Accepted 3 March 2015

CrossMark

For numbered affiliations see end of article.

Correspondence to Dr Ying-Chih Chuang; yingchih@tmu.edu.tw

\section{ABSTRACT}

Objectives: The theory of ecological unequal exchange explains how trade and various forms of economic activity create the problem of environmental degradation, and lead to the deterioration of population health. Based on this theory, our study examined the inter-relationship among economic characteristics, ecological footprints, $\mathrm{CO}_{2}$ emissions, infant mortality rates and under-5 mortality rates in low-income countries.

Design: A longitudinal ecological study design. Setting: Sixty-six low-income countries from 1980 to 2010 were included in the analyses. Data for each country represented an average of 23 years $(\mathrm{N}=1497)$.

Data sources: Data were from the World Development Indicators, UN Commodity Trade Statistics Database, Global Footprint Network and Polity IV Project.

Analyses: Linear mixed models with a spatial power covariance structure and a correlation that decreased over time were constructed to accommodate the repeated measures. Statistical analyses were conducted separately by sub-Saharan Africa, Latin America and other regions.

Results: After controlling for country-level sociodemographic characteristics, debt and manufacturing, economic activities were positively associated with infant mortality rates and under-5 mortality rates in sub-Saharan Africa. By contrast, export intensity and foreign investment were beneficial for reducing infant and under-5 mortality rates in Latin America and other regions. Although the ecological footprints and $\mathrm{CO}_{2}$ emissions did not mediate the relationship between economic characteristics and health outcomes, export intensity increased $\mathrm{CO}_{2}$ emissions, but reduced the ecological footprints in sub-Saharan Africa. By contrast, in Asia, the Middle East and North Africa, although export intensity was positively associated with the ecological footprints and also $\mathrm{CO}_{2}$ emissions, the percentage of exports to high-income countries was negatively associated with the ecological footprints.

Conclusions: This study suggested that environmental protection and economic development are important for reducing infant and under-5 mortality rates in lowincome countries.

\section{Strengths and limitations of this study}

- This study focused on the inter-relationship among trade, environmental pollutants, ecological footprints and population health, which have been rarely addressed in prior studies.

- This study used a large and longitudinal data set.

- The choice of indicators, which were strongly influenced by the available data, may have resulted in the exclusion of relevant variables.

\section{INTRODUCTION}

Political and economic characteristics, such as democracy and foreign investment, have been identified as determinants of population health in low-income countries. ${ }^{1}$ In the past decade, research has focused on the role of environmental degradation in the relationship between the political-economic factors and health conditions of a country. ${ }^{2}$ A growing number of studies have investigated how trade and various forms of economic activity create the problems of greenhouse gas emissions, forest degradation and water pollution, which may result in the deterioration of population health. ${ }^{2-6}$ Several studies have demonstrated that the influence of environmental degradation on population health is much greater in low-income countries than in high-income countries. ${ }^{5}$ This process has been attributed, at least partly, to the asymmetrical economic relationship between high-income and low-income countries. 7

Using the ecological unequal exchange theory, several researchers have attempted to explain how these economic structural forces influence environmental outcomes and human health in low-income countries. ${ }^{8}$ The 
theory of ecological unequal exchange claims that in global economic networks, countries have been divided into hierarchical positions through the international division of labour. High-income countries acquire inexpensive raw materials, opportunities for investment and markets for their products through trade and foreign investment. However, high-income countries are likely to disproportionately access the natural resources and sinkcapacity services of low-income countries. ${ }^{2}$ Consequently, high-income countries externalise their consumptionbased environmental costs and demands for natural resources to low-income countries. This process is typically represented by the vertical flow of manufactured products and raw materials from low-income to high-income countries. The long-term decline in the prices of primary goods in relation to the prices of processed goods creates an unbalanced economy, which further minimises the ability of governments in low-income countries to address public health and social problems. The ecological unequal exchange theory also argues that this unequal trade relationship increases the level of material consumption in high-income countries, but undermines the living standards, level of material consumption and health status of the population in low-income countries. ${ }^{9}$

Various studies have tested the ecological unequal exchange theory. ${ }^{2-7}$ Most studies have focused on how exports and manufacturing activities affect the environment of low-income countries, including their yearly average per capita rate of $\mathrm{CO}_{2}$ emissions, deforestation and organic water pollution. Nevertheless, few studies have investigated the effects of these factors on health and material consumption levels. ${ }^{2810}$ The present study contributes to this research area by adopting a longitudinal ecological sample from low-income countries. The conceptual model, which is based on the ecological unequal exchange theory, is shown in figure 1 . The following hypotheses were tested in this study: (1) debt, foreign investment, manufacturing economic activities, the percentage of exports to high-income countries and export intensity are positively associated with infant mortality rates (IMRs), and under-5 mortality rates (U5MRs); (2) debt, foreign investment, manufacturing economic activities, the percentage of exports to highincome countries and export intensity are negatively associated with material consumption (ecological footprint), and positively associated with $\mathrm{CO}_{2}$ emissions; and (3) material consumption and $\mathrm{CO}_{2}$ emissions mediate the relationships between debt, foreign investment, manufacturing economic activities, the percentage of exports to high-income countries, export intensity, and IMRs and U5MRs.

\section{METHODS}

A longitudinal ecological study design that focused on low-income countries during a 31-year period from 1980 to 2010 was used. We focused on low-income countries because prior studies have suggested that the relationship between economic activities and population health is much greater in low-income countries than in high-income countries. ${ }^{11}$ We selected a sample of countries according to the classification system developed by Clark and Beckfield. ${ }^{11}$ We excluded core countries, according to their definition, and excluded countries classified as high-income countries based on the definition established by the World Bank. ${ }^{5}$ Sixty-six lowincome countries were included in the analyses. The countries and years of data collection are listed in online supplementary appendix 1 . Data for each country represented an average of 23 years $(\mathrm{N}=1497)$.

\section{Measures}

The health outcome variables, namely IMRs and U5MRs, were measured as the probability of a child dying at less than 1 and 5 years of age (expressed as a rate per 1000 live births), respectively. These two variables, retrieved from the World Development Indicators (WDI), were selected as the outcome variables because of their wide acceptance and use as population health indicators. Studies have reported that these indicators are sensitive to structural changes and to rising epidemics that affect the wider population. ${ }^{12}$

Regarding the economic variables, data on debt and foreign investment stock were retrieved from the WDI and UN Commodity Trade Statistics Database, respectively. ${ }^{13} 14$ The total external debt stock as a percentage of gross national income was used as a debt indicator. Foreign direct investment stock refers to the inflows of investment for acquiring lasting management interest in an enterprise operating in an economy other than that of the investor. In this study, we divided the amount of foreign direct investment stock by gross domestic product (GDP). We anticipated that debt and foreign investment were positively associated with IMRs and U5MRs. ${ }^{15-17}$

In addition to debt and foreign investment, three economic variables were included in this study: the percentage of exports to high-income countries, manufacturing activities and export intensity. These three variables were gathered from the WDI. The percentage of exports to high-income countries refers to the sum of merchandise exports from the reporting countries to high-income countries. Previous studies have used this variable to examine the vertical flow of trade activities between lowincome and high-income countries. ${ }^{5}$ We also included manufacturing economic activity as a percentage of GDP, which is hypothesised to be positively related to environmental degradation, which further deteriorates population health. The variable of export intensity is calculated as a percentage of GDP. This variable measures the export intensity of a country. Because low-income countries are generally ill-equipped to handle environmental hazards, an increased amount of exports results in increased environmental pollution and deteriorated population health. ${ }^{7}$ 


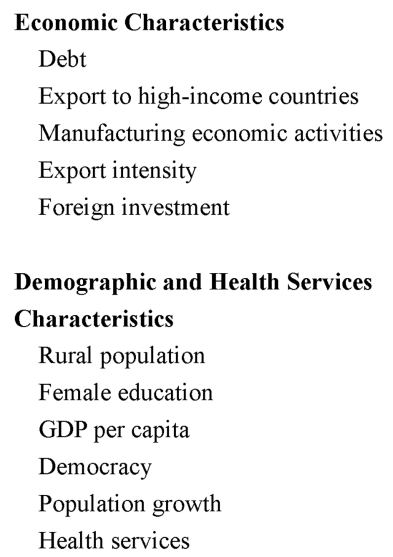

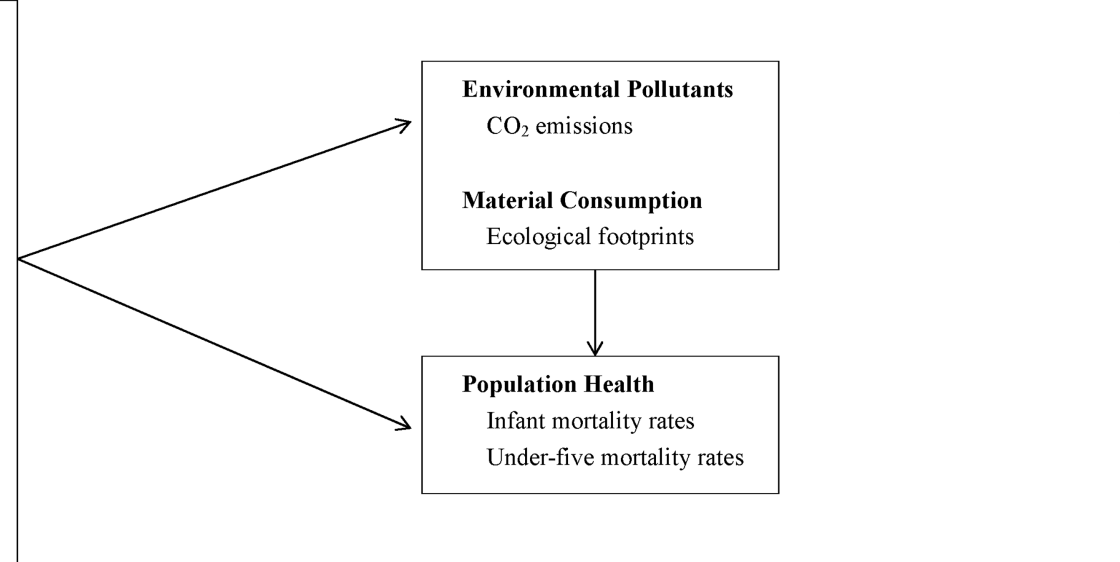

Figure 1 Inter-relationships among economic characteristics, environmental pollutants, material consumption and population health in low-income countries (GDP, gross domestic product).

Regarding the environmental variables, we used per capita footprints, obtained from the Global Footprint Network, as the indicator for comparing resource consumption across nations. ${ }^{18}$ An ecological footprint is defined as the amount of natural capital or land and water area required to support the resources consumed by a population. ${ }^{18}$ The measurement of footprints of a country, using global hectares (within and outside the borders of a country), is based on the total area required to produce the food and fibre that a country consumes, the space for accommodating its infrastructure and the ecosystems for absorbing its waste $\left(\mathrm{eg}, \mathrm{CO}_{2}\right)$. Footprints are composed of the following six subcomponents: cropland, grazing land, forests, fishing waters, built-up land and energy. ${ }^{2}$ We hypothesised that unequal trade activities conducted with high-income countries undermine the ecological footprints and deteriorate the population health in peripheral countries.

We used $\mathrm{CO}_{2}$ emissions (metric tons per capita), obtained from the WDI, to represent environmental pollutants. The $\mathrm{CO}_{2}$ emissions considered in this study are those that result from burning fossil fuels and manufacturing cement. ${ }^{19}$ Previous studies have demonstrated that per capita $\mathrm{CO}_{2}$ emissions in a country are associated with country-level economic development and population health. ${ }^{20}$ We used $\mathrm{CO}_{2}$ emissions, rather than deforestation and water pollution, to measure environmental degradation, because this indicator directly reflects the pollutants produced through manufacturing, and is less likely to be affected by the geographic context of a country than other indicators.

Regarding the demographic and health services variables, democracy scores were retrieved from the Polity IV Project. ${ }^{21}$ In brief, the score was based on three criteria: (1) openness and competitiveness in the recruitment of the chief executive; (2) constraints on the authority of the chief executive; and (3) political participation and opposition. Scores were then weighted and combined to generate a score ranging from -10 (autocracy) to 10 (democracy).

The indicator of health services was derived from the WDI. This indicator was measured using four items: the number of physicians per 1000 people, percentage of deliveries assisted by a skilled birth attendant, percentage of the population with access to safe water and immunisation coverage measured as the percentage of children aged 12-23 months who had received one dose of measles vaccine. ${ }^{22-26}$ Because these four items were measured on different scales, a quintile score for each item was developed for each country based on the score distribution. Subsequently, a composite score was created by averaging the quintile scores of the four items for each country and year. If a value was missing for certain items, the mean value of the other health service items was used to replace the missing value. ${ }^{27} 28$ A high score represented a high number of provided services, which should result in a lower IMR or U5MR. ${ }^{25}$

Female education was measured using the female primary school enrolment ratio, which is the number of females enrolled in primary schools in a given year, divided by the population of those of corresponding age for the same year. GDP per capita (constant 2005 international dollar) was log-transformed to correct for its skewed distribution. To consider the influence of rapid changes on demographic factors, this study also included the population growth rate. The period effect was recoded as 1980-1989, 1990-1999 and after 2000. We did not consider fertility rate because it is highly associated with both GDP per capita and female education. ${ }^{29-31}$

\section{Analysis}

Because of the nature of the repeated measurements conducted in our study design, we used linear mixed models (SAS Proc Mixed) with a spatial power covariance structure and a correlation that decreased over time to accommodate the possible problem of a serial 
correlation of errors. ${ }^{32}$ In cross-national longitudinal studies, it is common to have missing assessment waves within or across countries. We used this statistic model because a spatial power covariance structure accounts for uneven spacing of follow-up assessments. A spatial power model is similar to an autoregressive model in that observations closer in time are more correlated than observations farther apart, but it does not require the time between observations to be equal. Therefore, this model can accommodate different missing data points within or across countries. We also examined multicollinearity in the regression models by estimating the variance inflation factor and tolerance, and detected no multicollinearity problem.

Our mediation analyses followed the approach outlined by Baron and Kenny ${ }^{33}$ to assess whether environmental variables (ecological footprints and $\mathrm{CO}_{2}$ emissions) were the mediators between the independent variables (economic variables) and the dependent variables (health outcome variables). The first step is to regress the dependent variable on the independent variables to confirm that the independent variable (economic variables) is a significant predictor of the dependent variable (health outcome variables). The second step is to regress the mediator on the independent variable to confirm that the independent variable (economic variables) is a significant predictor of the mediator (environmental variables). The third step is to regress the dependent variable (health outcome variables) on both the independent variable (economic variables) and the mediator (environmental variables). If the relationship between the independent variable (economic variables) and the dependent variable (health outcome variables) disappears, then a mediating relationship is established. In our analyses, models were, first, fitted with economic variables and demographic variables. Then, models were fitted with economic variables, environmental variables and demographic variables. Last, we examined the relationship between the mediator and the outcome by regressing environmental variables on economic variables and demographic variables.

All of the analyses were conducted separately according to the geographical location of the countries because the geographical and historical circumstances of nations shape the relationship between economic variables and mortalities. We separated the analyses into three regions: sub-Saharan Africa, Latin America and other regions.

\section{RESULTS}

In table 1 , descriptive statistics for the study variables, separated by three regions (sub-Saharan Africa, Latin America and others), are shown. The levels of debt, foreign investment, rural population, population growth, IMR and U5MR were highest in sub-Saharan Africa. By contrast, the levels of exportation to high-income countries, manufacturing economic activities, export intensity, female education, GDP per capita, democracy, health services, physician density, assisted birth delivery, immunisation coverage, access to safe water, $\mathrm{CO}_{2}$ emissions and the ecological footprints were lower in sub-Saharan Africa than those in other regions.

Table 2 shows the results of the regression analyses, in which repeated measurements were conducted to examine the inter-relationship among economic characteristics, the ecological footprints, $\mathrm{CO}_{2}$ emissions and IMRs. The results are reported separately for the three regions. Models $1-3$ revealed that debt $(\beta=0.0001)$ was positively associated with IMRs in sub-Saharan Africa, both before and after including the ecological footprints and $\mathrm{CO}_{2}$ emissions. In Latin America, export intensity $(\beta=-0.0006)$ and foreign investment $(\beta=$ $-0.002)$ were both negatively associated with the IMRs in all models. Contrary to our prediction, in other regions, debt $(\beta=-0.0003)$, export intensity $(\beta=-0.0007$ in model 2 and $\beta=-0.0008$ in model 3) and foreign investment $(\beta=-0.001)$ were negatively associated with IMRs.

Table 3 shows the effects of economic characteristics, the ecological footprints and $\mathrm{CO}_{2}$ emissions on the U5MRs. Models $1-3$ revealed that debt $(\beta=0.0001)$ and manufacturing economic activities $(\beta=0.002)$ both contributed to the increase in the U5MRs in sub-Saharan Africa, before as well as after we added the environmental factors in the models. In Latin America, although manufacturing economic activities $(\beta=0.002)$ were positively associated with U5MRs, export intensity $(\beta=-0.0007)$ and foreign investment $(\beta=-0.002)$ were negatively associated with the U5MRs. In other regions, debt $(\beta=-0.0003)$, export intensity $(\beta=-0.0008$ in model 2 and $\beta=-0.0009$ in model 3) and foreign investment ( $\beta=-0.002$ in model 2 and $\beta=-0.001$ in model 3) were unexpectedly and negatively associated with the U5MRs, whereas per capita $\mathrm{CO}_{2}$ emissions $(\beta=0.019)$ were positively associated with the U5MRs.

According to tables 2 and 3, the ecological footprints and $\mathrm{CO}_{2}$ emissions per capita were not mediators between economic characteristics and health outcomes, because the coefficients of the economic variables were insubstantially changed after we added the ecological footprints and $\mathrm{CO}_{2}$ emissions to the regression models. Nevertheless, several economic characteristics, which are listed in table 4, can change the level of the ecological footprints and per capita $\mathrm{CO}_{2}$ emissions. The outcome variables of the ecological footprints and $\mathrm{CO}_{2}$ emissions per capita in table 4 were log-transformed for normality. The results suggested that in sub-Saharan Africa, export intensity was negatively associated with the ecological footprints $(\beta=-0.002)$ and positively associated with $\mathrm{CO}_{2}$ emissions $(\beta=0.004)$, suggesting that the export intensity affected the level of material consumption in that region. By contrast, in Latin America, foreign investment was negatively associated with $\mathrm{CO}_{2}$ emissions $(\beta=-0.003)$. In other regions, the percentage of exports to 


\begin{tabular}{|c|c|c|c|c|c|c|c|c|c|}
\hline \multirow[b]{2}{*}{ Variables } & \multicolumn{3}{|c|}{ Sub-Saharan Africa $(\mathrm{N}=675)$} & \multicolumn{3}{|c|}{ Latin America $(\mathrm{N}=297)$} & \multicolumn{3}{|c|}{ Others $(\mathrm{N}=525)$} \\
\hline & Mean & Minimum & Maximum & Mean & Minimum & Maximum & Mean & Minimum & Maximum \\
\hline \multicolumn{10}{|l|}{ Economic variables } \\
\hline Debt (\%) & 106.28 & 5.63 & 1252.43 & 79.10 & 17.82 & 825.65 & 54.35 & 0.24 & 355.54 \\
\hline Export to high-income countries (\%) & 67.00 & 6.76 & 98.82 & 67.14 & 14.14 & 96.73 & 62.41 & 6.06 & 96.64 \\
\hline Manufacturing activities (\%) & 9.98 & 1.87 & 37.16 & 17.58 & 3.68 & 31.96 & 17.61 & 0.00 & 96.58 \\
\hline Export intensity (\%) & 24.64 & 3.21 & 85.12 & 31.62 & 6.82 & 127.56 & 32.44 & 3.28 & 77.92 \\
\hline \multicolumn{10}{|l|}{ Demographic and health service variables } \\
\hline Foreign investment (\%) & 29.01 & 0.00 & 811.21 & 19.38 & 0.07 & 83.11 & 21.46 & 0.02 & 132.27 \\
\hline Rural population (\%) & 69.46 & 16.04 & 95.31 & 41.74 & 16.57 & 71.69 & 57.68 & 17.53 & 93.65 \\
\hline Female education (\%) & 80.10 & 16.73 & 158.72 & 111.21 & 92.36 & 149.92 & 93.53 & 31.15 & 125.30 \\
\hline GDP per capita (constant 2005 international dollar) & 1682 & 207 & 17441 & 5280 & 1563 & 12905 & 3486 & 577 & 12564 \\
\hline Democracy & -0.34 & -9.00 & 9.00 & 5.74 & -8.00 & 9.00 & 0.40 & -10.00 & 9.00 \\
\hline Population growth (\%) & 2.73 & -7.53 & 9.77 & 1.66 & -0.91 & 3.10 & 1.52 & -2.40 & 11.18 \\
\hline Health services & 2.03 & 1.00 & 4.50 & 3.72 & 2.00 & 5.00 & 3.64 & 1.00 & 5.00 \\
\hline Physician density (per 1000 people) & 0.11 & 0.01 & 0.86 & 0.99 & 0.11 & 2.89 & 1.35 & 0.03 & 4.41 \\
\hline Assisted birth delivery (\%) & 46.25 & 5.60 & 91.20 & 76.39 & 40.60 & 99.10 & 74.01 & 7.40 & 100.00 \\
\hline Immunisation coverage (\%) & 59.28 & 1.00 & 99.00 & 79.40 & 13.00 & 99.00 & 77.02 & 1.00 & 99.00 \\
\hline Access to safe water (\%) & 58.62 & 15.00 & 95.00 & 84.29 & 52.00 & 97.00 & 85.02 & 31.00 & 100.00 \\
\hline \multicolumn{10}{|l|}{ Environmental variables } \\
\hline Ecological footprints (global hectares) & 1.35 & 0.61 & 2.82 & 2.24 & 0.98 & 4.46 & 1.44 & 0.53 & 4.38 \\
\hline $\mathrm{CO}_{2}$ emissions (metric tons per capita) & 0.54 & 0.01 & 10.12 & 1.51 & 0.41 & 4.38 & 2.19 & 0.03 & 14.63 \\
\hline \multicolumn{10}{|l|}{ Health outcomes } \\
\hline Under-5 mortality (per 1000 live births) & 149.31 & 27.00 & 320.30 & 48.51 & 16.30 & 160.10 & 58.40 & 10.70 & 193.80 \\
\hline Infant mortality (per 1000 live births) & 89.62 & 22.70 & 153.80 & 37.41 & 14.00 & 106.00 & 45.09 & 9.20 & 127.40 \\
\hline
\end{tabular}


Table 2 Effects of economic characteristics, ecological footprints and $\mathrm{CO}_{2}$ emissions on infant mortality rates

\begin{tabular}{|c|c|c|c|c|c|c|c|c|c|}
\hline \multirow[b]{2}{*}{ Variables } & \multicolumn{3}{|c|}{ Sub-Saharan Africa $(\mathrm{N}=675)$} & \multicolumn{3}{|c|}{ Latin America $(\mathrm{N}=297)$} & \multicolumn{3}{|c|}{ Others $(\mathrm{N}=525)$} \\
\hline & Model 1 & Model 2 & Model 3 & Model 1 & Model 2 & Model 3 & Model 1 & Model 2 & Model 3 \\
\hline \multicolumn{10}{|l|}{ Economic variables } \\
\hline Debt (\%) & $\begin{array}{l}0.0001^{*} \dagger \\
(0.00003)\end{array}$ & $\begin{array}{l}0.0001^{*} \\
(0.00003)\end{array}$ & $\begin{array}{l}0.0001^{*} \\
(0.00003)\end{array}$ & $\begin{array}{l}0.0001 \\
(0.0001)\end{array}$ & $\begin{array}{l}0.0001 \\
(0.0001)\end{array}$ & $\begin{array}{l}0.0001 \\
(0.0001)\end{array}$ & $\begin{array}{l}-0.0003^{*} \\
(0.0001)\end{array}$ & $\begin{array}{l}-0.0003^{*} \\
(0.0001)\end{array}$ & $\begin{array}{l}-0.0003^{*} \\
(0.0001)\end{array}$ \\
\hline $\begin{array}{l}\text { Export to } \\
\text { high-income }\end{array}$ & 0.0001 & 0.0001 & 0.0001 & -0.00003 & -0.00002 & -0.00003 & -0.00002 & -0.00001 & -0.00003 \\
\hline Countries (\%) & 1) & .00 & .0001) & 0002) & 02) & $(0.0002)$ & 02) & $02)$ & $(0.0002)$ \\
\hline $\begin{array}{l}\text { Manu } \\
\text { activit }\end{array}$ & $\begin{array}{l}0 \\
(C\end{array}$ & $\begin{array}{l}0.001 \\
(0.0007)\end{array}$ & 107) & 09) & 209 & 009) & 1) & 03) & $\begin{array}{l}-0.00003 \\
(0.0003)\end{array}$ \\
\hline Expo & - & $\begin{array}{l}-0 . \\
(0.0\end{array}$ & & 3) & 3) & 06* & $\begin{array}{l}07^{*} \\
03)\end{array}$ & $\begin{array}{l}007^{*} \\
03)\end{array}$ & $\begin{array}{l}-0.0008^{*} \\
(0.0003)\end{array}$ \\
\hline $\begin{array}{l}\text { Foreign } \\
\text { investment (\%) }\end{array}$ & $\begin{array}{l}-0.0001 \\
(0.0001)\end{array}$ & $\begin{array}{l}-0.0001 \\
(0.0001)\end{array}$ & $\begin{array}{l}-0.0001 \\
(0.0001)\end{array}$ & $\begin{array}{l}-0.002^{*} \\
(0.0004)\end{array}$ & $\begin{array}{l}-0.002^{\star} \\
(0.0004)\end{array}$ & $\begin{array}{l}-0.002^{*} \\
(0.0004)\end{array}$ & $\begin{array}{l}-0.001^{*} \\
(0.0002)\end{array}$ & $\begin{array}{l}-0.001^{*} \\
(0.0002)\end{array}$ & $\begin{array}{l}-0.001^{\star} \\
(0.0002)\end{array}$ \\
\hline \multicolumn{10}{|c|}{ Demographic and health service variables } \\
\hline Rura & $7^{*}$ & $\begin{array}{l}0.028^{*} \\
(0.002)\end{array}$ & & & & & & & $\begin{array}{l}0.033^{*} \\
(0.003)\end{array}$ \\
\hline Female & $\begin{array}{l}-0.0 \\
(0.00\end{array}$ & $\begin{array}{l}-0.0 \\
(0.00\end{array}$ & $\begin{array}{l}-0.0007^{\star} \\
(0.0002)\end{array}$ & & & & & $\begin{array}{l}06^{*} \\
03)\end{array}$ & $\begin{array}{l}-0.0006^{\star} \\
(0.0003)\end{array}$ \\
\hline GDP & $\begin{array}{l}-0.0 \\
(0.00\end{array}$ & $\begin{array}{l}-0.0 \\
(0.00\end{array}$ & $\begin{array}{l}-0.0 \\
(0.00\end{array}$ & $\begin{array}{l}03^{*} \\
01)\end{array}$ & $\begin{array}{l}-0.0 \\
(0.00\end{array}$ & $\begin{array}{l}-0.0 \\
(0.0\end{array}$ & $\begin{array}{l}-0.0001^{*} \\
(0.00001)\end{array}$ & $\begin{array}{l}-0.0001^{*} \\
(0.00001)\end{array}$ & $\begin{array}{l}-0.0001^{*} \\
(0.00001)\end{array}$ \\
\hline Dem & $\begin{array}{l}-0.0007 \\
(0.0005)\end{array}$ & $\begin{array}{l}-0.0007 \\
(0.0005)\end{array}$ & $\begin{array}{l}-0.0007 \\
(0.0005)\end{array}$ & $\begin{array}{l}0.002^{*} \\
(0.0008)\end{array}$ & $\begin{array}{l}0.002^{*} \\
(0.0008)\end{array}$ & $\begin{array}{l}0.002^{*} \\
(0.0008)\end{array}$ & $\begin{array}{l}0.0003 \\
(0.0007)\end{array}$ & $\begin{array}{l}0.0002 \\
(0.0007)\end{array}$ & $\begin{array}{l}0.0002 \\
(0.0007)\end{array}$ \\
\hline Population growth & & & & & & & & & $\begin{array}{l}0.005 \\
(0.003)\end{array}$ \\
\hline Heal & $\begin{array}{l}-0.007 \\
(0.004)\end{array}$ & $\begin{array}{l}-0.007^{*} \\
(0.004)\end{array}$ & $\begin{array}{l}-0.007 \\
(0.004)\end{array}$ & $\begin{array}{l}-0.009^{*} \\
(0.004)\end{array}$ & $\begin{array}{l}-0.009^{*} \\
(0.004)\end{array}$ & $\begin{array}{l}-0.009^{*} \\
(0.004)\end{array}$ & $\begin{array}{l}-0.022^{*} \\
(0.006)\end{array}$ & $\begin{array}{l}-0.022^{*} \\
(0.006)\end{array}$ & $\begin{array}{l}-0.021^{*} \\
(0.006)\end{array}$ \\
\hline 1980sł & $\begin{array}{l}-0.007 \\
(0.008)\end{array}$ & $\begin{array}{l}-0.007 \\
(0.008)\end{array}$ & & & & & & & $\begin{array}{l}-0.056^{*} \\
(0.011)\end{array}$ \\
\hline $1990 \mathrm{~s}$ & $\begin{array}{l}0.006 \\
(0.006)\end{array}$ & $\begin{array}{l}0.006 \\
(0.006)\end{array}$ & $\begin{array}{l}0.006 \\
(0.006)\end{array}$ & $\begin{array}{l}-0.001 \\
(0.007)\end{array}$ & $\begin{array}{l}-0.0008 \\
(0.007)\end{array}$ & $\begin{array}{l}-0.001 \\
(0.007)\end{array}$ & $\begin{array}{l}-0.030^{*} \\
(0.009)\end{array}$ & $\begin{array}{l}-0.029^{*} \\
(0.009)\end{array}$ & $\begin{array}{l}-0.030^{*} \\
(0.009)\end{array}$ \\
\hline \multicolumn{10}{|l|}{ Environme } \\
\hline Ecolog & & $\begin{array}{l}0.006 \\
(0.007)\end{array}$ & & & $\begin{array}{l}-0.006 \\
(0.009)\end{array}$ & & & & \\
\hline $\mathrm{CO}_{2}$ emissions & & & $\begin{array}{l}-0.0013 \\
(0.0040)\end{array}$ & & & $\begin{array}{l}-0.0037 \\
(0.0106)\end{array}$ & & & $\begin{array}{l}0.0181 \\
(0.0051)\end{array}$ \\
\hline
\end{tabular}

"p $<$ < 0.05 .

tRegression coefficient.

†Reference group: year $>2000$.

GDP, gross domestic product.

high-income countries $(\beta=-0.003)$ and export intensity $(\beta=0.003)$, were negatively and positively associated, respectively, with the ecological footprints. Debt $(\beta=-0.002)$ and export intensity $(\beta=0.003)$ were negatively and positively associated, respectively, with per capita $\mathrm{CO}_{2}$ emissions.

\section{DISCUSSION}

This study applied the ecological unequal exchange theory to examine the relationship between economic factors and population health. The ecological unequal exchange theory was partially supported, and was more applicable to sub-Saharan Africa than to other regions. We determined that debt increases the IMRs and the U5MRs, whereas manufacturing economic activities increase the U5MRs in sub-Saharan Africa. External debt difficulties have historically plagued countries in sub-Saharan Africa, according to numerous studies. ${ }^{34}$ Researchers have emphasised that debt consumes a disproportionate amount of scarce resources at the expense of the provision of healthcare services. Thus, to pay back their debt, countries in sub-Saharan Africa agreed to implement structural economic reforms, which included the liberalisation of trade, major cuts to social and health expenditures, and the privatisation of basic services. ${ }^{35}$ Only a few empirical studies have analysed the influence of debt on population health in sub-Saharan Africa, but they all agreed that debt exerted deleterious effects on various health measures. ${ }^{36}$ The current study also demonstrated that manufacturing economic activities contribute to the increase in the U5MRs in sub-Saharan Africa. Although no previous studies 
Table 3 Effects of economic characteristics, ecological footprints and $\mathrm{CO}_{2}$ emissions on under- 5 mortality rates

\begin{tabular}{|c|c|c|c|c|c|c|c|c|c|}
\hline \multirow[b]{2}{*}{ Variables } & \multicolumn{3}{|c|}{ Sub-Saharan Africa $(\mathrm{N}=675)$} & \multicolumn{3}{|c|}{ Latin America $(\mathrm{N}=297)$} & \multicolumn{3}{|c|}{ Others $(\mathrm{N}=525)$} \\
\hline & Model 1 & Model 2 & Model 3 & Model 1 & Model 2 & Model 3 & Model 1 & Model 2 & Model 3 \\
\hline \multicolumn{10}{|l|}{ Economic variables } \\
\hline Debt $(\%)$ & $\begin{array}{r}0.0001^{*} \dagger \\
(0.00004)\end{array}$ & $\begin{array}{c}0.0001^{*} \\
(0.00004)\end{array}$ & $\begin{array}{c}0.0001^{*} \\
(0.00004)\end{array}$ & $\begin{array}{l}0.0001 \\
(0.00005)\end{array}$ & $\begin{array}{c}0.0001 \\
(0.00005)\end{array}$ & $\begin{array}{l}0.0001 \\
(0.00005)\end{array}$ & $\begin{array}{r}-0.0003^{*} \\
(0.0001)\end{array}$ & $\begin{array}{c}-0.0003^{*} \\
(0.00014)\end{array}$ & $\begin{array}{c}-0.0003^{*} \\
(0.0001)\end{array}$ \\
\hline Export to high-income & 0.0001 & 0.0001 & 0.0001 & -0.0001 & -0.00003 & -0.00005 & -0.0001 & -0.0001 & -0.0001 \\
\hline Countries (\%) & $(0.0001)$ & $(0.0001)$ & $(0.0001)$ & $(0.0002)$ & $(0.0002)$ & $(0.0002)$ & $(0.0002)$ & $(0.0002)$ & $(0.0002)$ \\
\hline Manufacturing & $0.002^{*}$ & $0.002^{*}$ & $0.002^{*}$ & $0.002^{*}$ & $0.002^{*}$ & $0.002^{*}$ & 0.0001 & 0.0001 & 0.00001 \\
\hline activities (\%) & $(0.0009)$ & $(0.0009)$ & $(0.0009)$ & $(0.001)$ & $(0.001)$ & $(0.001)$ & $(0.0003)$ & $(0.0003)$ & $(0.0003)$ \\
\hline sity (\%) & $\begin{array}{c}-0.0001 \\
(0.0003)\end{array}$ & $\begin{array}{c}-0.0001 \\
(0.0003)\end{array}$ & $\begin{array}{c}-0.0001 \\
(0.0003)\end{array}$ & $\begin{array}{r}-0.0007^{*} \\
(0.0003)\end{array}$ & $\begin{array}{r}-0.0007^{*} \\
(0.0003)\end{array}$ & $\begin{array}{r}-0.0007^{*} \\
(0.0003)\end{array}$ & $\begin{array}{r}-0.0008^{*} \\
(0.0003)\end{array}$ & $\begin{array}{r}-0.0008^{*} \\
(0.0003)\end{array}$ & $\begin{array}{r}-0.0009^{*} \\
(0.0003)\end{array}$ \\
\hline Foreic & $\begin{array}{c}-0.0001 \\
(0.0001)\end{array}$ & $\begin{array}{c}-0.0001 \\
(0.0001)\end{array}$ & $\begin{array}{c}-0.0001 \\
(0.0001)\end{array}$ & $\begin{array}{c}-0.002^{*} \\
(0.0004)\end{array}$ & $\begin{array}{l}-0.002^{*} \\
(0.0004)\end{array}$ & $\begin{array}{c}-0.002^{*} \\
(0.0004)\end{array}$ & $\begin{array}{c}-0.002^{*} \\
(0.0003)\end{array}$ & $\begin{array}{c}-0.002^{*} \\
(0.0003)\end{array}$ & $\begin{array}{c}-0.001^{*} \\
(0.0003)\end{array}$ \\
\hline \multicolumn{10}{|c|}{ Demographic and health service variables } \\
\hline Rural population (\%) & $\begin{array}{c}0.031^{*} \\
(0.003)\end{array}$ & $\begin{array}{c}0.031^{*} \\
(0.003)\end{array}$ & $\begin{array}{c}0.031^{*} \\
(0.003)\end{array}$ & $\begin{array}{c}0.059^{*} \\
(0.003)\end{array}$ & $\begin{array}{r}0.059^{\star} \\
(0.003)\end{array}$ & $\begin{array}{r}0.059^{\star} \\
(0.003)\end{array}$ & $\begin{array}{c}0.037^{\star} \\
(0.003)\end{array}$ & $\begin{array}{r}0.036^{*} \\
(0.003)\end{array}$ & $\begin{array}{r}0.036^{\star} \\
(0.003)\end{array}$ \\
\hline Fema & $\begin{array}{r}-0.0009^{\star} \\
(0.0002)\end{array}$ & $\begin{array}{r}-0.0008^{*} \\
(0.0002)\end{array}$ & $\begin{array}{r}-0.0009^{\star} \\
(0.0002)\end{array}$ & $\begin{array}{c}0.0009 \\
(0.0005)\end{array}$ & $\begin{array}{c}0.0009 \\
(0.0005)\end{array}$ & $\begin{array}{c}0.0009 \\
(0.0005)\end{array}$ & $\begin{array}{r}-0.0007^{\star} \\
(0.0003)\end{array}$ & $\begin{array}{r}-0.0007^{*} \\
(0.0003)\end{array}$ & $\begin{array}{r}-0.0008^{*} \\
(0.0003)\end{array}$ \\
\hline GDP per capita & $\begin{array}{c}-0.00001 \\
(0.00001)\end{array}$ & $\begin{array}{c}-0.00001 \\
(0.00001)\end{array}$ & $\begin{array}{c}-0.00001 \\
(0.00001)\end{array}$ & $\begin{array}{r}-0.00003^{*} \\
(0.00001)\end{array}$ & $\begin{array}{r}-0.00003^{*} \\
(0.00001)\end{array}$ & $\begin{array}{r}-0.00003^{*} \\
(0.00001)\end{array}$ & $\begin{array}{c}-0.0001^{*} \\
(0.00001)\end{array}$ & $\begin{array}{c}-0.0001^{*} \\
(0.00001)\end{array}$ & $\begin{array}{l}-0.0001^{*} \\
(0.00001)\end{array}$ \\
\hline Democracy & $\begin{array}{r}-0.0008 \\
(0.0007)\end{array}$ & $\begin{array}{c}-0.0008 \\
(0.0007)\end{array}$ & $\begin{array}{c}-0.0008 \\
(0.0007)\end{array}$ & $\begin{array}{c}0.002^{*} \\
(0.0008)\end{array}$ & $\begin{array}{c}0.002^{*} \\
(0.0008)\end{array}$ & $\begin{array}{l}0.002^{*} \\
(0.0008)\end{array}$ & $\begin{array}{c}0.0002 \\
(0.0008)\end{array}$ & $\begin{array}{c}0.0002 \\
(0.0008)\end{array}$ & $\begin{array}{c}0.0002 \\
(0.0008)\end{array}$ \\
\hline Population growth & $\begin{array}{c}0.002 \\
(0.003)\end{array}$ & $\begin{array}{c}0.002 \\
(0.003)\end{array}$ & $\begin{array}{c}0.002 \\
(0.003)\end{array}$ & $\begin{array}{c}0.096^{*} \\
(0.025)\end{array}$ & $\begin{array}{c}0.095^{*} \\
(0.025)\end{array}$ & $\begin{array}{c}0.096^{*} \\
(0.025)\end{array}$ & $\begin{array}{c}0.005 \\
(0.003)\end{array}$ & $\begin{array}{c}0.005 \\
(0.003)\end{array}$ & $\begin{array}{c}0.005 \\
(0.003)\end{array}$ \\
\hline Health services & $\begin{array}{r}-0.014^{*} \\
(0.005)\end{array}$ & $\begin{array}{r}-0.014^{*} \\
(0.005)\end{array}$ & $\begin{array}{r}-0.014^{*} \\
(0.005)\end{array}$ & $\begin{array}{r}-0.011^{\star} \\
(0.004)\end{array}$ & $\begin{array}{r}-0.011^{*} \\
(0.004)\end{array}$ & $\begin{array}{r}-0.011^{*} \\
(0.004)\end{array}$ & $\begin{array}{r}-0.026^{*} \\
(0.006)\end{array}$ & $\begin{array}{r}-0.026^{*} \\
(0.006)\end{array}$ & $\begin{array}{r}-0.025^{*} \\
(0.006)\end{array}$ \\
\hline 1980sł & $\begin{array}{c}-0.008 \\
(0.010)\end{array}$ & $\begin{array}{c}-0.009 \\
(0.010)\end{array}$ & $\begin{array}{c}-0.008 \\
(0.010)\end{array}$ & $\begin{array}{c}-0.016 \\
(0.010)\end{array}$ & $\begin{array}{c}-0.016 \\
(0.010)\end{array}$ & $\begin{array}{c}-0.016 \\
(0.010)\end{array}$ & $\begin{array}{r}-0.061^{*} \\
(0.012)\end{array}$ & $\begin{array}{r}-0.060^{*} \\
(0.012)\end{array}$ & $\begin{array}{r}-0.061^{*} \\
(0.012)\end{array}$ \\
\hline $1990 \mathrm{~s}$ & $\begin{array}{c}0.007 \\
(0.007)\end{array}$ & $\begin{array}{c}0.007 \\
(0.007)\end{array}$ & $\begin{array}{c}0.007 \\
(0.007)\end{array}$ & $\begin{array}{c}-0.002 \\
(0.007)\end{array}$ & $\begin{array}{c}-0.002 \\
(0.007)\end{array}$ & $\begin{array}{c}-0.002 \\
(0.007)\end{array}$ & $\begin{array}{r}-0.033^{*} \\
(0.010)\end{array}$ & $\begin{array}{r}-0.032^{*} \\
(0.010)\end{array}$ & $\begin{array}{r}-0.033^{*} \\
(0.010)\end{array}$ \\
\hline Enviro & & & & & & & & & \\
\hline Ecological footprint & & $\begin{array}{c}0.007 \\
(0.010)\end{array}$ & & & $\begin{array}{c}-0.008 \\
(0.010)\end{array}$ & & & $\begin{array}{c}0.005 \\
(0.0006)\end{array}$ & \\
\hline $\mathrm{CO}_{2}$ emissions & & & $\begin{array}{c}-0.0007 \\
(0.005)\end{array}$ & & & $\begin{array}{c}-0.003 \\
(0.011)\end{array}$ & & & $\begin{array}{c}0.019^{*} \\
(0.006)\end{array}$ \\
\hline
\end{tabular}

${ }^{*} \mathrm{p}<0.05$.

†Regression coefficient.

$\ddagger$ Reference group: year $>2000$.

GDP, gross domestic product.

have assessed the effects of manufacturing economic activities on IMRs or U5MRs, several reports have suggested that low-income countries with a large industrial sector exhibit high per capita levels of $\mathrm{CO}_{2}$, noxious gases and sulfur dioxide, and also produce high levels of other contaminants such as organic water pollutants, which result in high mortality and morbidity. ${ }^{20}$

Similar to sub-Saharan Africa, in Latin America, manufacturing economic activities result in increased U5MRs. However, contrary to our hypothesis, the results revealed that foreign investment and export intensity contribute to reducing IMRs and U5MRs in Latin America as well as in other regions. In addition, debt was negatively associated with IMRs and U5MRs among the countries in the 'other regions' category, which included countries in Asia, the Middle East and Northern Africa. This result suggests that these economic activities reduce child mortality through positive effects on economic growth, infrastructure creation and enhanced development. ${ }^{13}{ }^{37}$ For example, a previous study revealed a two-way flow pattern between foreign investment and population health, suggesting that foreign investment improved the health of a population, and the healthy population subsequently increased productivity and foreign investment. ${ }^{38}$ Although the beneficial influence of these economic activities seems to encourage open economic policies and increased economic involvement by foreign countries, researchers have warned that in low-income countries, the effectiveness of international trade investment depends on the political capacity of the national government, including its bargaining power and negotiation skills in its dealings with high-income countries. ${ }^{39}$ Therefore, government capacity plays a major role in determining whether these economic activities can be transformed into long-term economic and structural development, which can benefit the well-being of citizens.

Although we did not determine whether the ecological footprints and per capita $\mathrm{CO}_{2}$ emissions were the mediators between economic characteristics, and IMRs 
Table 4 Effects of economic characteristics on the ecological footprints and $\mathrm{CO}_{2}$ emissions

\begin{tabular}{|c|c|c|c|c|c|c|}
\hline \multirow[b]{2}{*}{ Variables } & \multicolumn{2}{|c|}{ Sub-Saharan Africa $(\mathrm{N}=675)$} & \multicolumn{2}{|c|}{ Latin America ( $\mathrm{N}=297)$} & \multicolumn{2}{|c|}{ Others $(\mathrm{N}=525)$} \\
\hline & $\begin{array}{l}\text { Ecological } \\
\text { footprints }\end{array}$ & $\mathrm{CO}_{2}$ & $\begin{array}{l}\text { Ecological } \\
\text { footprints }\end{array}$ & $\mathrm{CO}_{2}$ & $\begin{array}{l}\text { Ecological } \\
\text { footprints }\end{array}$ & $\mathrm{CO}_{2}$ \\
\hline \multicolumn{7}{|l|}{ Economic variables } \\
\hline Debt (\%) & $\begin{array}{l}0.00001 \dagger \\
(0.0001)\end{array}$ & $\begin{array}{r}-0.0002 \\
(0.0002)\end{array}$ & $\begin{array}{l}-0.0002 \\
(0.0001)\end{array}$ & $\begin{array}{l}-0.0001 \\
(0.0002)\end{array}$ & $\begin{array}{l}-0.0004 \\
(0.0005)\end{array}$ & $\begin{array}{l}-0.002^{*} \\
(0.0004)\end{array}$ \\
\hline Export to high-income & 0.0003 & 0.0001 & 0.0006 & 0.0008 & $-0.003^{*}$ & 0.0001 \\
\hline $\begin{array}{l}\text { Manufacturing } \\
\text { activities (\%) }\end{array}$ & $\begin{array}{l}-0.003 \\
(0.002)\end{array}$ & $\begin{array}{l}0.006 \\
(0.005)\end{array}$ & $\begin{array}{l}0.0003 \\
(0.003)\end{array}$ & $\begin{array}{c}-0.0001 \\
(0.004)\end{array}$ & $\begin{array}{l}0.001 \\
(0.001)\end{array}$ & $\begin{array}{c}0.002 \\
(0.001)\end{array}$ \\
\hline Export intensity (\%) & $\begin{array}{l}-0.002^{*} \\
(0.0007)\end{array}$ & $\begin{array}{r}0.004^{*} \\
(0.002)\end{array}$ & $\begin{array}{l}0.001 \\
(0.0007)\end{array}$ & $\begin{array}{c}0.002 \\
(0.001)\end{array}$ & $\begin{array}{r}0.003^{*} \\
(0.001)\end{array}$ & $\begin{array}{r}0.003^{*} \\
(0.001)\end{array}$ \\
\hline Foreign investment (\%) & $\begin{array}{l}-0.0005 \\
(0.0003)\end{array}$ & $\begin{array}{c}0.0002 \\
(0.0008)\end{array}$ & $\begin{array}{c}0.00002 \\
(0.0010)\end{array}$ & $\begin{array}{r}-0.003^{*} \\
(0.001)\end{array}$ & $\begin{array}{c}0.002 \\
(0.001)\end{array}$ & $\begin{array}{c}0.0002 \\
(0.0008)\end{array}$ \\
\hline \multicolumn{7}{|l|}{ Demographic variables } \\
\hline Rural population (\%) & $\begin{array}{c}-0.003 \\
(0.003)\end{array}$ & $\begin{array}{r}-0.036^{\star} \\
(0.008)\end{array}$ & $\begin{array}{c}0.008 \\
(0.005)\end{array}$ & $\begin{array}{c}-0.008 \\
(0.007)\end{array}$ & $\begin{array}{r}-0.004^{*} \\
(0.002)\end{array}$ & $\begin{array}{r}-0.033^{*} \\
(0.007)\end{array}$ \\
\hline Female education (\%) & $\begin{array}{c}-0.0008 \\
(0.0006)\end{array}$ & $\begin{array}{c}0.0008 \\
(0.001)\end{array}$ & $\begin{array}{c}0.002 \\
(0.001)\end{array}$ & $\begin{array}{c}0.002 \\
(0.002)\end{array}$ & $\begin{array}{c}0.003^{*} \\
(0.001)\end{array}$ & $\begin{array}{c}0.002 \\
(0.001)\end{array}$ \\
\hline GDP per capita & $\begin{array}{l}0.00003^{*} \\
-0.00001\end{array}$ & $\begin{array}{l}0.0001^{*} \\
(0.00004)\end{array}$ & $\begin{array}{r}0.0001^{*} \\
-0.00002\end{array}$ & $\begin{array}{l}0.0001^{*} \\
(0.00002)\end{array}$ & $\begin{array}{l}0.0001^{*} \\
(0.00001)\end{array}$ & $\begin{array}{l}0.0001^{*} \\
(0.00002)\end{array}$ \\
\hline Democracy & $\begin{array}{l}0.0002 \\
(0.002)\end{array}$ & $\begin{array}{c}0.004 \\
(0.004)\end{array}$ & $\begin{array}{c}-0.001 \\
(0.002)\end{array}$ & $\begin{array}{r}-0.002 \\
(0.003)\end{array}$ & $\begin{array}{c}0.004 \\
(0.003)\end{array}$ & $\begin{array}{c}0.001 \\
(0.003)\end{array}$ \\
\hline Population growth & $\begin{array}{l}0.015^{\star} \\
(0.007)\end{array}$ & $\begin{array}{c}0.009 \\
(0.016)\end{array}$ & $\begin{array}{c}-0.011 \\
(0.054)\end{array}$ & $\begin{array}{r}-0.132 \\
(0.073)\end{array}$ & $\begin{array}{c}0.008 \\
(0.013)\end{array}$ & $\begin{array}{c}-0.003 \\
(0.010)\end{array}$ \\
\hline 1980sł & $\begin{array}{l}0.029 \\
(0.025)\end{array}$ & $\begin{array}{r}-0.137^{*} \\
(0.059)\end{array}$ & $\begin{array}{l}0.030 \\
(0.026)\end{array}$ & $\begin{array}{c}0.026 \\
(0.036)\end{array}$ & $\begin{array}{r}-0.120^{*} \\
(0.046)\end{array}$ & $\begin{array}{c}0.042 \\
(0.038)\end{array}$ \\
\hline 1990s & $\begin{array}{l}0.025 \\
(0.019)\end{array}$ & $\begin{array}{r}-0.132^{*} \\
(0.044)\end{array}$ & $\begin{array}{l}0.019 \\
(0.020)\end{array}$ & $\begin{array}{c}0.012 \\
(0.027)\end{array}$ & $\begin{array}{r}-0.108^{*} \\
(0.038)\end{array}$ & $\begin{array}{c}0.047 \\
(0.030)\end{array}$ \\
\hline $\begin{array}{l}{ }^{*} p<0.05 \text {. } \\
\text { †Regression coefficient. } \\
\text { †Reference group: year }>2000 \\
\text { GDP, gross domestic product. }\end{array}$ & & & & & & \\
\hline
\end{tabular}

and U5MRs, we discovered that export intensity increases the level of $\mathrm{CO}_{2}$ emissions, but decreases the ecological footprints in sub-Saharan Africa. Therefore, the theoretical explanation that the unequal trade relationship results in environmental pollution and decreased material consumption in developing countries seems to be applicable to sub-Saharan Africa. By contrast, export intensity increases the ecological footprints and the per capita $\mathrm{CO}_{2}$ emissions in other countries in Asia, the Middle East and Northern Africa. Although $\mathrm{CO}_{2}$ emissions increase in these countries because of the effects of exports, these countries are capable of using their resources to increase economic growth and improve the living standard of the population. In addition, our results suggest that in other regions, an increased percentage of exports to high-income countries can reduce the ecological footprints in these countries. This finding suggests that the export of natural resources, goods and services from low-income countries could greatly influence the environmental and structural contexts, and further decrease the living standards of low-income countries. Similar results have been reported in a previous study. ${ }^{5}$
The findings of this study have several limitations. First, the choice of indicators, which were strongly influenced by the available data, may have resulted in the exclusion of relevant variables. Missing data in the available data sets may also have been a problem. Difficulties in collecting data from low-income countries have been documented in relevant studies. ${ }^{19}$ Second, although the ecological footprint is a powerful communication tool, and has been widely used to measure material consumption, this indicator was criticised for neglecting numerous ecological demands. ${ }^{40}$ Third, this is a repeated cross-sectional study; therefore, the causal relationship between the economic variables and outcomes should be interpreted cautiously.

\section{CONCLUSION}

This study demonstrated that the inter-relationship among economic factors, IMRs, U5MRs, ecological footprints and $\mathrm{CO}_{2}$ emissions differed by geographical location. Future research should therefore incorporate additional indicators delineating various economic and social contexts, and replicate the studies over time and 
in various settings. The present study also revealed that policymakers should consider the importance of protecting the environment in addition to economic reactivation and growth. In various historical and cultural contexts, no single solution exists to address the balance between environmental conservation and economic development.

\section{Author affiliations}

${ }^{1}$ School of Public Health, College of Public Health and Nutrition, Taipei Medical University, Taipei City, Taiwan

${ }^{2}$ Department of Public Health, School of Medicine, College of Medicine, Taipei Medical University, Taipei City, Taiwan

Contributors Y-CC designed the study, analysed the data and wrote the manuscript. Y-LH and $\mathrm{C}-\mathrm{YH}$ gave advice on the interpretation, and revised the manuscript. S-CC and K-CT collected the data. All authors read and approved the final manuscript.

Funding This study was funded by the Ministry of Science and Technology of Taiwan (Grant No. Most 102-2410-H-038-006- to Y-CC).

\section{Competing interests None.}

Ethics approval This study used publicly available data from the World Development Indicators, UN Commodity Trade Statistics Database, Polity IV Project and Global Footprint Network, and thus was exempt from review by the Human Investigation Committee (HIC).

Provenance and peer review Not commissioned; externally peer reviewed.

Data sharing statement Additional data can be accessed via the Dryad data repository at http://datadryad.org/ with the doi:10.5061/dryad.5jg7f.

Open Access This is an Open Access article distributed in accordance with the Creative Commons Attribution Non Commercial (CC BY-NC 4.0) license, which permits others to distribute, remix, adapt, build upon this work noncommercially, and license their derivative works on different terms, provided the original work is properly cited and the use is non-commercial. See: http:// creativecommons.org/licenses/by-nc/4.0/

\section{REFERENCES}

1. Chuang K-Y, Sung P-W, Chang C-J, et al. Political and economic characteristics as moderators of the relationship between health services and infant mortality in less-developed countries. J Epidemiol Community Health 2013;67:1006-12.

2. Rice J. Material consumption and social well-being within the periphery of the world economy: an ecological analysis of maternal mortality. Soc Sci Res 2008;37:1292-309.

3. Jorgenson AK, Clark B. Societies consuming nature: a panel study of the ecological footprints of nations, 1960-2003. Soc Sci Res 2011;40:226-44.

4. Jorgenson AK, Austin K, Dick C. Ecologically unequal exchange and the resource consumption/environmental degradation paradox: a panel study of less-developed countries, 1970-2000. Int J Comp Soc 2009;50:263-84.

5. Jorgenson AK. The sociology of ecologically unequal exchange and carbon dioxide emission, 1960-2005. Soc Sci Res 2012;41:242-52.

6. Jorgenson AK. Unequal ecological exchange and environmental degradation: a theoretical proposition and cross-national study of deforestation, 1990-2000. Rural Soc 2006;71:685-712.

7. Shandra JM, Shor E, London B. World polity, unequal ecological exchange, and organic water pollution: a cross-national analysis of developing nations. Hum Econ Rev 2009;16.

8. Jorgenson AK, Burns TJ. Globalization, the environment, and infant mortality: a cross-national study. Humboldt J Soc Rel 2004;28:7-52.

9. Shandra JM. Economic dependency, repression, and deforestation: a quantitative, cross-national analysis. Sociol Inq 2007;77:543-71.

10. Jorgenson AK. Political-economic integration, industrial pollution and human health a panel study of less-developed countries, 19802000. Int Soc 2009;24:115-43.
11. Clark R, Beckfield J. A new trichotomous measure of world-system position using the international trade network. Int J Comp Soc 2009;50:5-38.

12. Olafsdottir AE, Reidpath DD, Pokhrel S, et al. Health systems performance in sub-Saharan Africa: governance, outcome and equity. BMC Public Health 2011;11:237.

13. Shen C, Williamson JB. Maternal mortality, women's status, and economic dependency in less developed countries: a cross-national analysis. Soc Sci Med 1999;49:197-214.

14. Shen C, Williamson JB. Child mortality, women's status, economic dependency, and state strength: a cross-national study of less developed countries. Social Forces 1997;76:667-94.

15. Shandra JM, Shor E, London B. Debt, structural adjustment, and organic water pollution: a cross-national analysis. Organ Environ 2008:21:38-55.

16. Shandra JM, Nobles JE, London B, et al. Multinational corporations, democracy and child mortality: a quantitative, cross-national analysis of developing countries. Soc Ind Res 2005;73:267-93.

17. Shandra JM, Nobles J, London B, et al. Dependency, democracy, and infant mortality: a quantitative, cross-national analysis of less developed countries. Soc Sci Med 2004;59:321-33.

18. Network GF. Footprint for nations. 2011.

19. World Bank. World development indicator. 2010

20. Jorgenson AK, Dick C, Mahutga MC. Foreign investment dependence and the environment: an ecostructural approach. Soc Probl 2007;54:371-94.

21. Munck G, Verkuilen J. Conceptualizing and measuring democracy: evaluating alternative indices. Comp Polit Stud 2002;35:5-34.

22. Shimouchi A, Ozasa K, Hayashi K. Immunization coverage and infant mortality rate in developing countries. Asia Pac J Public Health 1994;7:228-32.

23. Andoh SY, Umezaki M, Nakamura K, et al. Correlation between national income, HIV/AIDS and political status and mortalities in African countries. Public Health 2006;120:624-33.

24. McGuire JW. Democracy, health care, and under-5 mortality: a cross-national study of developing countries. Boston, MA: The Conferernce on Democracy and Human Development: A Global Inquiry, 2004.

25. McGuire JW. Basic health care provision and under-5 mortality: a cross-national study of developing countries. World Dev 2006:34:405-25.

26. Muldoon K, Galway L, Nakajima M, et al. Health system determinants of infant, child and maternal mortality: a cross-sectiona study of UN member countries. Glob Health 2011;7:42.

27. Nedjat S, Montazeri A, Holakouie K, et al. Psychometric properties of the Iranian interview-administered version of the world health organization's quality of life questionnaire: a population-based study. BMC Health Serv Res 2008;8:61.

28. Seecharan GA, Andresen EM, Norris K, et al. Parents' assessment of quality of care and grief following a child's death. JAMA Pediatr 2004;158:515-20.

29. Bballe E, Mpuga P. Female education, contraceptive use, and fertility: evidence from Uganda. J Sustainable Dev 2011;6:20-47.

30. Jain AK, Ross JA. Fertility differences among developing countries: are they still related to family planning program efforts and social settings? Int Perspect Sex Reprod Health 2012;38:15-22.

31. Weil DN. Economic growth. Boston: Addison-Wesley, 2004.

32. SAS/STAT(R). 9.2 user's guide, 2nd. Cary, NC, 2009.

33. Baron RM, Kenny DA. The moderator-mediator variable distinction in social psychological research: conceptual, strategic, and statistical considerations. J Pers Soc Psychol 1986;51:1173-82.

34. Greene J. The external debt problem of sub-Saharan Africa. Int Monetary Fund 1989;36:836-74.

35. Cheru F. Debt, adjustment and the politics of effective response to HIV/AIDS in Africa. Third World Q 2002;23:299-312.

36. Mogford L. Structural determinants of child mortality in sub-Saharan Africa: a cross-national study of economic and social influences from 1970 to 1997. Soc Biol 2004;51:94-120.

37. Soysa ID. Foreign direct investment, democracy and development: assessing contours, correlates, and concomitants of globalization. London: Routledge, 2003.

38. Alsan M, Bloom DE, Canning D. The effect of population health on foreign direct investment inflows to low- and middle-income countries. World Dev 2006;34:613-39.

39. Sharma B, Gani A. The effects of foreign direct investment on human development. Glob Econ J 2004;4:9.

40. Lenzen M, Murray S. The ecological footprint: issues and trends. Sydney: University of Sydney, 2003. 